\title{
OPEN
}

\section{0 \\ Selling Words: An Economic History of Bookselling}

\section{Jaki Hawker}

\begin{abstract}
A summary of the fiscal relationship between text, readers, publishers, bookshops, and legislation, this chapter argues that it is the economics of the consumer market that will shape the academic book of the future. Suggesting that demand for text intersects across a global marketplace, this chapter predicts a future in which the distinctions between physical and digital text, and Open Access and commercial publication, are so blurred as to be indistinguishable. Case studies from past, current, and future fiscal strategy illuminate the economics of reading, publishing and bookselling online and on the high street, and are used to consider a future where a marketplace governed by personal choice rather than publisher provision will determine textual form.
\end{abstract}

Keywords: accessibility; bookselling; choice; consumer; demand; digital text; ebook; economics; innovation; market; Open Access; physical book; publishing; reading

Lyons, Rebecca E. and Samantha J. Rayner (eds). The Academic Book of the Future. Basingstoke: Palgrave Macmillan, 2016. DOI: 10.1057/9781137595775.0018. 
I make my living from words. Language is the primary currency of communication, and although my fiscal relationship with text may be a little more direct than yours (even if I am not, unlike Dickens, paid by the word but rather by the book) we all have an undeniable personal investment in the commerce of trafficking text. It is this relationship between markets, customers, and equations of supply and demand that I'm going to discuss in this chapter.

Academic texts, and platforms for disseminating academic texts, have changed faster and more fundamentally than any other sector of the bookselling market. Academic texts today encompass printed paper books and online digital learning; Open Access journals and peer-reviewed blog posts; text that is fixed and text that is infinitely flexible. Some academic resources may not be delivered in words at all; text to speech transcripts; image; sound or video. Equally, the exchange of currency that makes academic publication possible has evolved in tandem with publication methods. Publication is as likely today to be financed at the source as part of a research proposal, by a host institution, or by the author, as it is to be funded by post-publication purchase.

Whatever the text and however it is funded and curated, for a bookseller the primary factor in determining the success or failure of any project is success in the market, whether that success is measured in sales or in read counts. Arguably, it is that market, the textual consumer, the reader - of commercial or Open Access text - and their economic demands that will shape the future of academic text.

Pressure to publish ('publish or perish') accompanies most academic careers. ${ }^{1}$ With tenure linked to publication, writing and re-writing papers for journals has become an end in itself, and publication citations are a necessary footnote to any academic profile. Even commissioned text may be unfunded or unpaid. While the volume of articles and papers submitted for publication increases yearly, librarians, spending on average 70 per cent of their materials budget on journals (thus accounting for the vast majority of journal sales ${ }^{2}$ ), are under immense pressure to cut costs. Journal publishers were quick to move to digital copy, but library purchasing of digital text has revealed an uneven demand, with some articles in constant circulation and others never accessed. ${ }^{3}$ In conversation, when discussing digital publishing with academic librarians, two issues dominated: journal bundling and double dipping - attempts by traditional publishers to maximise a marketplace where digital data has revealed consumer choice and user-directed purchasing has become the 
selection criteria for purchase. Journal sales to libraries have inevitably decreased. As a result, while the pressure to publish will not diminish, the economic capacity of traditional publishers to support academic publication in either digital or physical form will continue to erode.

Given this combination of bloated product, decreasing market, and continued pressure to publish, it's not surprising that Open Access publishing was pioneered in the journal marketplace. In 1996, 24 per cent of papers published were made available through online Open Access sources. In 2014, that figure, supported by European legislation and both government and industry funding, was 50 per cent. ${ }^{4}$ Free access promotes scholarship (The Hague Declaration ${ }^{5}$ ), and it would be easy to assume that the online journal publishing marketplace supported by new publishing houses is infinite. But it is not. Just as traditional journal publishing requires a market to be sustainable, so too does online publishing. The metrics may be different, with income deriving from pre-publication payments and library subscriptions, where financial success is measured by clicks rather than direct sales, but it is still a marketplace, and one affected inevitably by the mechanisms of demand and supply. At this point in time, in a rapidly developing online market, editors are hungry for content and contributors. As the market matures, financial viability and investment accountability will become the measure of publication, and as learning moves further online, as more students and academics access single articles rather than full journals, authors will be judged not only by peer review but by the actions of readers across the globe. Demand will inevitably govern content, and it's possible to conceive of text being judged not by peer review, but by the swipe-and-like judgement of a dating site model. No clicks, no sales or return on expenditure, no publishing contract. In this challenging environment, I'd argue that a critical examination of the impetus to publish is long overdue.

Traditional book publishers have been posing the same questions why publish? - for years. The answer is that, despite the availability of both legitimate Open Access text and torrent downloads, readers still buy books. And for booksellers, academic books, lengthy explorations of a particular theme or concept, intended to instruct and elucidate a reader or a student, however broad the definition of student, are the heart of our trade.

Every year, I contact academic teaching staff and discuss their undergraduate and postgraduate reading lists. I plan launches for local publications and delve into publisher catalogues. I've watched lecturers 
develop the ways in which they use text for teaching across subject areas and platforms, spoken to editors and developers, explored digital learning and social media, and discussed text with students. I've seen initiatives succeed and fail in a market that changes every year. In these days of immediate student feedback and rapid technological development, change is both increasingly easy to quantify, with sales figures and read counts freely available, and more difficult to predict. Feedback does not always predict consumer choices, and publisher innovation is not always the best fit for a reader.

Student feedback has suggested that students want easy-to-access text cheaper, and preferably free. ${ }^{6}$ With universities in England and Wales funding undergraduate tuition via student fees, this feedback has fuelled a move to university-funded ebooks and Open Access textbooks and journals. Publishers have responded with dedicated learning platforms and interactive text. Yet at the same time, student usage has suggested a very different picture. John Kelly of Oxford University Press reports that in 2014 only 6 per cent of students provided with an ebook and physical book bundle accessed the ebook; 35 per cent of students provided with an ebook and additional digital resources accessed both.? Ironically, that 35 per cent is exactly the proportion of students I would have expected to purchase a physical textbook if no digital text was provided. Even in courses where use of digital material is mandatory, 4 per cent of students never view those resources. Here in Edinburgh, two major courses moved to Open Access text following student feedback. Yet in 2013 and 2014, 25 per cent of those same students willingly purchased physical copies of a textbook they could read and use, free to them, online. ${ }^{8}$

The last ten years have seen many traditional publishers and start-ups develop new models of financing, structuring and using text. In the American market, where textbook prices leverage far higher publisher returns and corresponding student costs than in the UK (see Kirtsaeng v. John Wiley \& Sons, Inc. ${ }^{9}$ ), just as in journal publishing, financial constraints have led to a corresponding rise in the Open Access text market. At first glance, Open Access offers a perfect solution to students. Text is freely available to both lecturer and student, fully accessible within the limitations of the platform chosen, and exclusive of copyright restraints. And yet. 'I don't like the text,' one lecturer confided to me. 'My students want free material, but this isn't the level I want to be teaching.' Open Access publisher Flat World lasted five years on start-up capital of $\$ 26.5$ million before introducing charges for student access 
to text in 2012. It was already charging for lecturer access. ${ }^{10}$ Bookboon, using material gathered from non-copyrighted text across the web to compile textbooks, kindly promises 'less than $15 \%$ advertising. ${ }^{11}$ I asked author and publisher David Diez of OpenIntro how he financed the print edition of his Open Access textbook. He laughed. 'Lots of volunteer labour,' he said. And I've raised a sardonic eyebrow at some Open Access textbooks priced, in their print versions, at well over the market rate for traditional textbooks. Don't forget the 25 per cent of students, educated through digital learning platforms throughout their school careers, who still use printed text, or the 80 per cent of teenagers purchasing print books in preference to ebooks. ${ }^{12}$

Studying the market for textbooks, in my experience the most successful innovations of the last five years have been paper and ebook bundles, where the same text is available in different formats but in a single purchase, and course-specific custom publications. Sales of these publications can outstrip traditional books by factors of up to 200 per cent. Paper and ebook bundles offer students choice, flexibility, portability and a competitive price, particularly useful for those universities folding textbook provision into student tuition fees. Custom textbooks are equally useful for a lecturer, offering dedicated text, although are far less popular with students tied to a unique purchase point. Both options may or may not come with dedicated course resources, although the relevance of those resources to the course being taught may vary. ${ }^{13}$

One innovation I've seen gaining ground this year is the custom textbook produced, not by the publisher or the lecturer, but as a collaborative enterprise involving both teaching staff and students on a particular course. These curated texts can be both physically and digitally available, tend to involve both interactive media and fixed text, and have often been constructed to respond rapidly to new research and findings in that particular study area.

The factors common to all these success stories is that they are mixed media creations, available on at least two platforms, containing text that includes a high degree of personalised content. They are structured towards active rather than passive reading, with students interacting with both text and lecturer through learning platforms, social media, and in class. Obviously, these are factors that do not necessarily translate to every academic book, but I do expect to see innovations undertaken for the lucrative student market spread to general academic publishing. 
For me, the bottom line in considering the academic book of the future is not 'What does it look like?' but 'Does it sell?' If you'd asked me five years ago, I would not have predicted that in 2015 I'd still be working in an academic bookshop whose primary source of income remains physical textbook sales, supplemented but not replaced by digital sales. Now, I'm beginning to wonder if in 2020, students and academics will still prefer paper to pixels. It may look as though I'm arguing for the traditional print book, but what I'm actually saying is that it's very easy to be seduced by the bright lights of technological innovation without considering what readers want. And what readers want is choice, both in learning material, and in format.

Today, I expect academic publishers to print a revised edition of an out-of-date textbook in both digital and physical forms, provide online teaching resources for an iconic edition accessible across multiple devices, or commission a new manuscript about a particular area of study if the proposed title offers a new and credible interpretation. I expect publishers to offer a text that embraces new research and offers flexible update options online and in print. I expect searchable text, the capacity to store my library on a device no larger than the palm of my hand, and to be able to read in the bath. I expect to be running my fingers along my bookshelves and remember the places and times where I bought much loved editions of much loved books. I expect to engage with text, author, and publisher via social media and in person in my own bookshop. I also expect other readers to want different things from their own texts, and as a bookseller I want the capacity to be able to provide that choice.

I've talked at length about a market driven and financed by consumer demand, and of the ways in which I believe that the market - the reader's choices and preferences - will shape the academic text of the future. But there are other aspects to a global marketplace and consumer culture, with little financial muscle but of immense social influence, which I trust and hope will enhance academic text in the future. The ability to access the printed word is not available to every consumer. Text to speech, variable on-screen text justification, accessible texts, fonts and backgrounds, visual rather than textual explanation, animation rather than tabular data description are all innovations deriving from a marketplace which is not yet financially powerful, but will be. As learning becomes a truly international activity, the demand for accessible text will grow, and resources devoted to development and publication will be correspondingly greater. Of all the options the creators of academic text will explore in the future, 
of all the excitement creative choice will bring to reading, this particular option is my own personal favourite textual future.

I'd argue that the book of the future will be inclusive, collaborative, available across multiple platforms and in a number of formats. Whether pre- or post-publication funded, I'd also expect that book to be financially viable. Bookshops, successful bookshops, online or in a university, make hard choices. If a book doesn't sell, and if there is no market, you're not going to find it on our shelves. It's very easy to predict, in the excitement and discovery of Open Access text and learning platform development, with print on demand capacity and custom publications, that the future of text contains infinite possibilities. Perhaps it does. But I believe, just as a bookshop makes choices governed by the consumers, those infinite possibilities will be created, enabled and shaped, by the market. In my eyes, it is our readers and their personal and financial choices who are as important in the creation of text as the publisher, and it is the reader who will determine the success or failure of any textual project, whatever form that project may take.

Luckily, we're all readers.

\section{Notes}

1 C. Cerejo (2013) 'Navigating through the Pressure to Publish', Editage Insights, http://www.editage.com/insights/navigating-through-the-pressure-to-publish, accessed 4 September 2015.

2 Publishers Communications Group (2015) Library Budget Predictions for 2015, http://www.pcgplus.com/wp-content/uploads/2015/o1/Library-BudgetPredictions-for-2015.pdf, accessed 7 August 2015.

3 É. Archambault, D. Amyot, P. Deschamps, A. Nicol, F. Provencher, L. Rebout and G. Roberge (2014) Proportion of Open Access Papers Published in Peer-Reviewed Journals at the European and World Levels 1996-2013, http:// science-metrix.com/files/science-metrix/publications/d_1.8_sm_ec_dg-rtd_ proportion_oa_1996-2013_v11p.pdf, accessed 7 August 2015.

4 J. Priem, D. Taraborelli, P. Groth and C. Neylon (2010) Altmetrics: A Manifesto, http://altmetrics.org/manifesto, accessed 4 September 2015.

5 LIBER (2015) The Hague Declaration on Knowledge Discovery in the Digital Age, http://thehaguedeclaration.com, accessed 7 August 2015

6 Student feedback panels, The Academic Professional and Specialist Group Conference (Booksellers Association) 2013, 2014, 2015. Most recent programme, www.booksellers.org.uk, accessed 10 July 2015 
7 J. Kelly (May 2015). Internal company reporting in conversation with Jaki Hawker.

8 J. Hawker. Internal company sales reports, Blackwell's.

9 Supreme Court Kirtsaeng v. John Wiley \& Sons, Inc., http://www. supremecourt.gov (home page), accessed 7 August 2015.

10 D. Lederman (2012) 'Fleeing rom "Free", Inside Higher Ed, https://www. insidehighered.com/news/2012/11/05/flat-worlds-shift-gears-and-what-itmeans-open-textbook-publishing, accessed 7 August 2015.

11 Bookboon blog (6oo+ Open Access textbooks), http://bookboon.com, accessed 7 August 2015.

12 E. Drabble (16 December 2014) 'Teens Prefer the Printed Page to ebooks', Guardian, http://www.theguardian.com/childrens-books-site/2014/dec/16/ teens-ebooks-ereaders-survey, accessed 7 August 2015.

13 I. Lapowsky (2015) 'What Schools Must Learn from LA's iPad Debacle', Wired, http://www.wired.com/2015/o5/los-angeles-edtech/, accessed 7 August 2015.

(c) Except where otherwise noted, this work is licensed under a
Creative Commons Attribution 4.0 International License. To view a copy of this license, visit https://creativecommons.org/version4 